Aging Across the United States 


$$
\text { ar }
$$




\section{Aging Across the United States}

Matching Need to States' Differing Opportunities and Services

The Pennsylvania State University Press

University Park, Pennsylvania 
Lockhart, Charles, 1944- .

Aging across the United States : matching need to states' differing opportunities and services / Charles Lockhart and Jean Giles-Sims.

p. $\mathrm{cm}$.

Includes bibliographical references and index.

Summary: "Compares services and opportunities for older Americans by region and state. Examines the criteria of recreational lifestyle, meaningful contributions and supportive communities, affordability and safety, health and high-quality medical care, and accessible, high-quality long-term care"Provided by publisher.

ISBN 978-0-271-03756-1 (alk. paper)

1. Older persons-United States-States.

2. Aging-United States-States.

I. Giles-Sims, Jean.

II. Title.

HQ1064.U5L63 2010

$305.260973-\mathrm{dc2} 2$

2010021723

Copyright $\odot 2010$ The Pennsylvania State University All rights reserved

Printed in the United States of America

Published by The Pennsylvania State University Press, University Park, PA 16802-1003

The Pennsylvania State University Press is a member of the Association of American University Presses.

It is the policy of The Pennsylvania State University Press to use acid-free paper. Publications on uncoated stock satisfy the minimum requirements of American National Standard for Information Sciences-Permanence of Paper for Printed Library Material, ANSI Z39.48-1992.

This book is printed on Natures Natural, which contains $50 \%$ post-consumer waste. 
In Loving Memory of Our Parents:

Wilbur and Dorothy Grindell

Charles H., Gertrude, and Elizabeth Lockhart 
